\author{
JAKUB KOCIUBIŃSKI \\ ORCID: 0000-0002-4391-7439 \\ Uniwersytet Wrocławski \\ Katedra Prawa Międzynarodowego i Europejskiego
}

\title{
RACJONALNE PRZEDSIĘBIORSTWO JAKO RACJONALNE ZAŁOŻENIE PRAWODAWCY W OBSZARZE PRAWA KONKURENCJI - ZARYS PROBLEMU
}

\begin{abstract}
Abstrakt: Niniejszy artykuł poświęcony jest zagadnieniom związanym z zakresem i ograniczeniami stosowania założenia o racjonalności profesjonalnych uczestników rynku przez prawodawców i regulatorów w obszarze prawa konkurencji. Analizie poddane zostały kwestie interpretacji pojęcia racjonalności ekonomicznej w naukach prawnych, możliwości prognozowania racjonalnego kursu przedsiębiorstw i ocena, czy wykorzystanie dorobku nauk ekonomicznych może przełożyć się na racjonalność prawodawcy.
\end{abstract}

Słowa kluczowe: racjonalność, prawo konkurencji, ograniczona racjonalność, bardziej ekonomiczne podejście

\section{WPROWADZENIE — PERSPEKTYWA BADAWCZA}

Pojęcie racjonalności stosowane jest w szeroko pojętych naukach prawnych w odniesieniu do działań prawodawcy, a w obszarze prawa gospodarczego także do modelowych zachowań profesjonalnych uczestników życia gospodarczego. W pierwszym wypadku funkcjonuje jako oświeceniowa w swej istocie idea posługiwania się przez normodawcę obiektywną wiedzą naukową podczas tworzenia narzędzi prawnych, stanowiąc tym samym kryterium oceny prawa ${ }^{1}$. W drugim zaś odnosi się do postępowania przedsiębiorstwa maksymalizującego stopień realizacji celu przy optymalnym (w sensie Pareto) wykorzystaniu posia-

${ }^{1}$ Zob. m.in. W. Gromski, Racjonalny prawodawca, [w:] Encyklopedia prawa, red. U. Kalina-Prasznic, Warszawa 2007; L. Wintgens, The rational legislator revisited. Bounded rationality and legisprudence, [w:] The Rationality and Justification of Legislation, red. L. Wintgens, D. Oliver-Lalana, Heidelberg 2013, s. 1-31. 
danych, ograniczonych zasobów² ${ }^{2}$ Choć powyższe znaczenia wydają się intuicyjnie akceptowalne, wynikając z wiedzy nomotetycznej, to przez ogólnikowość funkcjonują jako swego rodzaju superfluum, pozostając wieloznaczne i w wielu wypadkach kontrfaktyczne, a tym samym bywają nadużywane jako hasło pozbawione treści ${ }^{3}$.

Wobec tego analiza prowadzona w niniejszym artykule, mająca charakter propedeutyczny ze względu na ograniczenia objętościowe, skupi się na kwestii możliwości i wyzwań związanych z zaadaptowaniem założenia o ekonomicznej racjonalności profesjonalnych uczestników rynku na potrzeby tworzenia i stosowania prawa konkurencji, a w konsekwencji na ocenie, czy taka adaptacja może przełożyć się na racjonalność prawodawcy.

\section{RACJONALNOŚĆ W PRAWIE KONKURENCJI}

Nawiązując do perspektywy badawczej zarysowanej we wstępie, zasadne wydaje się przytoczenie poglądu Herberta Hovenkampa, że fundamentem prawa konkurencji (w oryginale Antitrust) jest założenie, że przedsiębiorstwa zachowują się racjonalnie ${ }^{4}$. Oparcie się na tak zwanej teorii racjonalnego wyboru dominującej teorii badającej modele zachowań ekonomicznych — nie wyklucza wprawdzie możliwości istnienia irracjonalnych działan, ale postrzega je w kategoriach występujących losowo jednostkowych anomalii, przez co nie zaburza to ogólnej konkluzji o racjonalności działań profesjonalnych uczestników rynku

Jako podstawę dalszych rozważań dotyczących funkcjonowania tytułowej koncepcji w prawie konkurencji przyjąć można „klasyczną” definicję racjonalności autorstwa Miltona Friedmana. Zgodnie z nią racjonalne będą działania przedsiębiorstw wolne od obciążenia decyzjami zbiorowości, podejmowane w celu maksymalizacji własnej użytecznoścí. Patrząc tę motywację przez pryzmat dorobku ekonomicznej tak zwanej szkoły z Chicago, która wywarła bardzo silny wpływ na kształt prawa antytrustowego/konkurencji, można przyjąć, że działanie

2 P. Kotlarek, Racjonalność w ujęciu ekonomii behawioralnej, „Studia Ekonomiczne” 2014, nr 180, cz. 1, s. 106-116; H.A. Simon, Method and Appraisal in Economics, Cambridge, MA 1976, s. $129 \mathrm{n}$.

3 C.R. Leslie, Rationality analysis in antitrust, „University of Pennsylvania Law Review” 158, 2010, nr 2, s. 265-266.

${ }^{4}$ H. Hovenkamp, The Antitrust Enterprise, Cambridge, MA 2005, s. 134.

5 S. Issacharoff, Can there be a behavioral law and economics?, „Vanderbilt Law Review” 51, 1998, s. 1730 .

${ }^{6}$ M. Zouboulakis, The Varieties of Economic Rationality: From Adam Smith to Contemporary Behavioural and Evolutionary Economics, Cheltenham 2014, s. 69. 
maksymalnie użyteczne dla przedsiębiorstwa będzie działaniem wiążącym się z powstaniem możliwie największego zysku?

Choć na pewnym poziomie ogólności przytoczona definicja jest prawdziwa, bo rzeczywiście dążeniem do maksymalizacji zysków można wyjaśnić większość decyzji biznesowych, to analiza, zwłaszcza z perspektywy prawodawcy rozważającego skutki ingerencji w gospodarkę, wskazuje jej zasadnicze mankamenty — opiera się ona bowiem na kontrfaktycznym założeniu, że istnieje obiektywnie optymalny kurs maksymalizacji funkcji celu. Sugerowałby to, że możliwe byłoby stworzenie ex ante teoretycznego modelu racjonalnego zachowania na potrzeby oceny skutków regulacji. Choć taki model mógłby być formalnie poprawny (to jest uzasadnialny na gruncie neoklasycznej teorii ekonomii), to jednocześnie pominięcie specyficznych uwarunkowań lokalnych modyfikujących zachowania profesjonalnych uczestników rynku, związanych między innymi z dostępem do informacji w momencie podejmowania decyzji, ogranicza jego użyteczność dla prawodawcy ${ }^{8}$.

Ponadto, gdyby bezwarunkowo przyjąć ścisłe powiązanie maksymalizacji zysków z racjonalnością, wówczas każde działanie generujące straty byłoby irracjonalne $\mathrm{z}$ definicji. Tymczasem wydaje się, że rzeczywistość gospodarcza nie pozwala na sformułowanie tak kategorycznego wniosku9 ${ }^{9}$. Można bowiem wskazać, że ocena racjonalności może być dokonana tylko w odniesieniu do celu (preferencji), do którego dąży dane przedsiębiorstwo, i tylko w świetle uwarunkowań istniejących w momencie podejmowania decyzji.

Nawet mówiąc wyłącznie o maksymalizacji zysków, nie jest jasne - i cytowane źródła nie dostarczają odpowiedzi na to pytanie — w jakiej perspektywie czasowej ów zysk miałby się zmaterializować. Należy bowiem zauważyć, że każda decyzja przedsiębiorstwa w przedstawianym kontekście, nawet jeżeli ostatecznie przyniesie założone rezultaty (co nie jest nigdy pewne), to te na ogól nie zmaterializują się do razu ${ }^{10}$. Akceptowalny i planowany horyzont czasowy, w jakim ma się pojawić zysk, będzie unikalny dla konkretnego stanu faktycznego.

Tym samym inna będzie percepcja racjonalności konkretnych działań przedsiębiorstw analizowanych w świetle ich krótkoterminowej taktycznej przydatności

7 P.E. Areeda, H. Hovenkamp, Antitrust Law: An Analysis of Antitrust Principles and Their Application, New York 2006, s. 140; R.B. Korobkin, T.S. Ulen, Law and behavioral science: Removing the rationality assumption from law and economics, „California Law Review” 88, 2000, nr 4, s. 1066.

8 J. Elster, When rationality fails, [w:] The Limits of Rationality, red. K.S. Cook, M. Levi, Chicago-London 1990, s. 21; P. Kotlarek, op. cit., s. 107.

${ }^{9}$ C.R. Leslie, op. cit., s. 273-274.

10 Jako przykład można przywołać operacje koncentracyjne i restrukturyzacyjne, które zanim (jeżeli) przyniosą pożądany rezultat synergii części składowych czy też poprawę sprawności operacyjnej, będą wiązać się z często wieloletnimi kosztami dostosowania poszczególnych komponentów organizmu gospodarczego. 
i docelowej strategicznej użyteczności ${ }^{11}$. Tym bardziej że okoliczności wynikające $\mathrm{z}$ differentia specifica konkretnych podmiotów są możliwe do analizy przez prawodawcę post factum, a nie w momencie podejmowania decyzji dotyczącej ingerencji. Problemem dla prawodawcy/regulatora będzie także rozróżnienie działań irracjonalnych, które statystycznie zawsze będą występować, a które powinny być traktowane jako irrelewantna wariacja ogólnie racjonalnego kursu od działania racjonalnego, ale niewpisującego się w cel maksymalizacji zysków, albo takiego, którego ocena racjonalności ex ante będzie inna od tej dokonanej ex post (na przykład nietrafiona inwestycja), co sprawia, że przyjęcie abstrakcyjnie pojmowanej racjonalności ekonomicznej przez prawodawcę, choć ogólnie poprawnie, ma poważne ograniczenia.

\section{DOSTĘP DO INFORMACJI I RYZYKO}

Wybór racjonalnego kursu przez przedsiębiorstwo — tak zwana decyzja końcowa — zależeć też będzie od tego, jakie jest postrzeganie ryzyka przez dany podmiot i jak duże ryzyko jest on w stanie zaakceptować ${ }^{12}$. Pojęcie ryzyka w opisywanym kontekście - jako czynnika modyfikującego percepcję racjonalności - (analogicznie jak tytułowa koncepcja racjonalności) jest wieloznaczne. Obejmuje ryzyko zarówno specyficzne, uwzględniające uwarunkowania właściwe dla konkretnego przedsiębiorstwa, jak i gospodarcze, wyrażane za pomocą kowariancji odchyleń pojawiających się zmian w ogólnym rozwoju gospodarczym ${ }^{13}$. Funkcjonuje równocześnie jako kategoria niemierzalna, oparta na semantycznym i w znacznej mierze intuicyjnym rozumieniu samego pojęcia, wyrażająca ogólną „niepewność”, oraz mierzalna, korzystająca z dorobku matematyki i statystyki ${ }^{14}$.

Jeżeli ryzyko (mierzalne lub nie) nie jest możliwe do wyeliminowania, to oznacza, że możliwość określenia jednego obiektywnie optymalnego kursu nie istnieje $\mathrm{w}$ momencie podejmowania danej decyzji ${ }^{15}$. Analiza ex post $\mathrm{w}$ momencie, gdy dostępne są już wszystkie informacje i wyznaczenie racjonalnego, optymalnego, działania w odniesieniu do już dokonanej decyzji jest zupełnie irrelewantne dla prawodawcy/regulatora, który tej wiedzy potrzebuje w momencie podejmowania decyzji o interwencji. Ryzyko będące następstwem asymetrii informacji będzie

11 Zob. M. Rutherford, Rational expectations and keynesian uncertainty: A critique, „Journal of Post Keynesian Economics" 6, 1984, nr 3, s. 377-387.

12 Zob. R.B. McKenzie, Predictably Rational? In Search of Defenses for Rational Behavior in Economics, Heidelberg-Dordrecht 2010, s. 118-124.

13 A. Zachorowska, Ryzyko działalności inwestycyjnej przedsiębiorstw, Warszawa 2006, s. 59.

14 M. Piśniak, Ryzyko w teorii podejmowania decyzji, „Zeszyty Naukowe Politechniki Częstochowskiej — Zarządzanie” 2015, nr 19, s. 120.

15 C.R. Leslie, op. cit., s. 279; J.F. Tomer, What is behavioral economics?, „The Journal of Socio-Economics" 36, 2007, nr 3, s. 463-479. 
więc czynnikiem ograniczającym dokładność analiz racjonalności gospodarczej dokonywanej ex ante. Jest to jednak nieodłączny element gospodarki rynkowej, dlatego nie może być traktowany jako przesłanka odejścia od przeprowadzenia analizy rynku, lecz wzięta pod uwagę jako czynnik w procesie decyzyjnym legislatora/regulatora.

Natomiast dla przedsiębiorstw działających w warunkach ograniczonych możliwości zbierania i analizy informacji konieczne staje się przyjęcie uproszczonej strategii podejmowania decyzji (tak zwanej stopping rule zgodnie z nomenklaturą cytowanego Herberta A. Simona) ${ }^{16}$. Będzie to racjonalny krok, prowadzący tym samym do podjęcia subiektywnie optymalnej decyzji w danej sytuacji (nawet jeżeli nie jest ona obiektywnie optymalna), gdyż obiektywnie optymalne rozwiązanie byłoby praktycznie niemożliwe do wypracowania ${ }^{17}$.

Choć uwzględnienie przez legislatora ograniczeń możliwości wytyczenia obiektywnie racjonalnego kursu przez przedsiębiorstwa lepiej odzwierciedla realia rynkowe, to wciąż wymagane będzie dokonanie prognozy procesów decyzyjnych profesjonalnych uczestników rynku. Tymczasem w ramach swojej działalności także legislator/regulator występujący jako ,zewnętrzny obserwator” (a nie uczestnik określonych procesów ekonomicznych) nie jest wolny od problemu niedysponowania pełnymi informacjami ${ }^{18}$. Nawet jeżeli przyjąć, że szeroko pojęte struktury państwowe mają większe możliwości gromadzenia i przetwarzana informacji dotyczących procesów zachodzących na rynku, to i tak nie będzie możliwości zgromadzenia wszystkich informacji dotyczących wspomnianych „wewnętrznych" uwarunkowań, swoistych dla konkretnych przedsiębiorstw ${ }^{19}$.

Rodzi to pytanie, na ile kompletnymi informacjami powinien dysponować prawodawca, żeby można było stwierdzić, że jest w stanie określić racjonalne zachowanie przedsiębiorstw reagujących na przygotowywany instrument prawny. Nie ulega wątpliwości, że analiza dokonana na podstawie niepełnych danych nosić będzie cechy aproksymacji, ale otwarte pozostaje pytanie, czy możliwe jest stwierdzenie za pomocą obiektywnych kryteriów, jaka mediana błędu będzie lub powinna być akceptowalna dla władzy publicznej podczas stosowania racjonalności gospodarczej jako narzędzia prognostycznego umożliwiającego przewidzenie reakcji podmiotów na potrzeby oceny skutków regulacji.

16 H.A. Simon, A behavioral model of rational choice, „The Quarterly Journal of Economics” 69, 1995, nr 1, s. 99-118.

17 R.B. Korobkin, T.S. Ulen, op. cit., s. 1077-1078.

18 Choć można wskazywać, że działaniom prawodawczym/regulacyjnym również towarzyszy pewne ryzyko rozumiane jako niepewność, to nie można porównywać go z ryzykiem, którego doświadczają przedsiębiorstwa ze względu na zasadniczo różne konsekwencje, które mogą ponieść profesjonalni uczestnicy rynku z jednej strony, a władza publiczna z drugiej.

19 R. Selten, Features of experimentally observed bounded rationality, „European Economic Review" 42, 1998, nr 3-5, s. 413; H.A. Simon, A behavioral model..., s. 241. 


\section{OGRANICZONA RACJONALNOŚĆ}

Skupienie się na samym niedostatku danych ekonomicznych wspomnianych w poprzednim paragrafie pomija kwestie źródeł motywacji konkretnych uczestników rynku. Przyjęcie a priori schematu homo oeconomicus, dającego prymat przesłankom ekonomicznym w dokonywanych wyborach, zdaje się pomijać inne determinanty decyzji immanentnie przynależne ludziom, którzy indywidualnie lub kolektywnie odpowiadają przecież ostatecznie za decyzje wszystkich przedsiębiorstw ${ }^{20}$. Odnosząc się do tego problemu, J.M. Buchanan wyraził pogląd, że bez znajomości natury ludzkiej wszelkie modele ekonomiczne odwzorowujące wybrane aspekty rzeczywistości będą obarczone bardzo poważnym błędem ${ }^{21}$.

Dorobek Herberta A. Simona dotyczący racjonalności działań przedsiębiorców jest w tym kontekście użyteczną bazą heurystyczną, koncentrując się na jej subiektywnym charakterze. Dlatego w późniejszych pracach H.A. Simon definiował racjonalne zachowanie - określone mianem ograniczonej racjonalności (bounded rationality) - jako uwzględniające poziom dostępu do informacji danego podmiotu gospodarującego i możliwość ich analizy ${ }^{22}$. Oznacza to zatem odejście od postrzegania przedsiębiorstw jako zdolnych do podejmowania absolutnie optymalnych decyzji pojmowanych w kategoriach „zero-jedynkowej” klasyfikacji jako obiektywnie dobre, złe czy też racjonalne lub irracjonalne; uwzględniana jest praktyczna możliwość wypracowania określonego rezultatu.

W warunkach ograniczonej racjonalności działania przedsiębiorstw są motywowane zaspokajaniem danego celu tego podmiotu (satisficing), nie zaś dążeniem do wypracowania obiektywnie największej użyteczności ${ }^{23}$. Podmiot podejmujący decyzje przyjmie więc pierwszy akceptowalny wariant, nie zaś ten wiążący się z najlepszym dla niego rezultatem ${ }^{24}$. Wybór dokonany przez przedsiębiorstwo niekoniecznie wynika więc z niedysponowania informacjami wystarczającymi do oceny optymalnego kursu, lecz z praktycznych uwarunkowań (na przykład ilości posiadanych zasobów). Innymi słowy racjonalne będzie działanie dające efekt „wystarczający”, nie zaś „najlepszy”.

Ponadto należy odnotować, że ocena racjonalności działań może być dokonywana tylko w odniesieniu do założonych wcześniej celów, nie zaś jako pewnego rodzaju obiektywny konstrukt funkcjonujący w oderwaniu od uwarunkowań strategicznych danego przedsiębiorstwa. W związku z tym przywoływane twierdze-

${ }^{20}$ M. Kalinowski, Ekonomiczne meandry racjonalności, „Studia Ekonomiczne” 180, 2014, cz. 1, s. 76-84.

21 J.M. Buchanan, There is a science of economics, [w:] idem, Post-Socialist Political Economy: Selected Essays, Cheltenham 1997, s. 10.

${ }^{22}$ H.A. Simon, A behavioral model..., s. 241.

${ }^{23}$ H.A. Simon, Models of Man: Social and Rational; Mathematical Essays on Rational Human Behavior in Society Setting, New York 1957, s. 270-271.

${ }^{24}$ Ibidem. 
nie, że racjonalność podmiotów gospodarujących sprowadza się do podejmowania działań maksymalizujących użyteczność (utility), jest fałszywe bez wyznaczenia, co konstytuuje ową użyteczność 25 .

Abstrakcyjna, gdyż oderwana od differentia specifica danego rynku, analiza działań przedsiębiorstw nie umożliwi więc sformułowania na potrzeby prognozy sytuacji rynkowych ich dychotomicznej klasyfikacji jako racjonalne lub irracjonalne. Ocena w tym względzie i tym samym percepcja optymalnego rezultatu będzie bowiem determinowana katalogiem celów przedsiębiorstwa, które dodatkowo dynamicznie ewoluują wraz ze zmianami sytuacji rynkowej i mogą być wewnętrznie zróżnicowane w zależności od tego, czy w danym momencie priorytetem jest realizacja długoterminowego założenia strategicznego, czy doraźnej potrzeby taktycznej. Ponadto wszystkie cele mogą dodatkowo się zmieniać wskutek wystąpienia nieprzewidywalnych — z samej definicji — zdarzeń losowych, jak zmiany koniunktury czy struktury właścicielskiej przedsiębiorstwa itp. (czyli opisywanego ryzyka rozumianego jako niekwantyfikowalna niepewność $)^{26}$. Innymi słowy, przywoływany „wystarczający” efekt będzie skutkiem pierwszego realistycznego wyboru akceptowalnego w danych konkretnych okolicznościach faktycznych.

\section{PODSUMOWANIE - OPERACJONALIZACJA KONCEPCJI RACJONALNEGO PRZEDSIĘBIORSTWA}

W obliczu przeprowadzonych dotychczas rozważań poświęconych koncepcji racjonalności i jej praktycznych ograniczeń zdaniem autora nie można traktować racjonalności uczestników rynku jako prostego założenia prawodawcy, gdyż sama w sobie jest ona pozbawiona treści. Będzie tylko pustą konstrukcją semantyczną opartą na nieuporządkowanej i w znacznej mierze intuicyjnej wiedzy nomotetycznej poszczególnych decydentów, jeżeli nie zostanie wsparta dorobkiem nauk ekonomicznych, na podstawie których zostanie skonstruowana matryca racjonalnych zachowań na rynku (na ile to jest możliwe w świetle przedstawionych ograniczeń). Dlatego wydaje się, że racjonalność w prezentowanym znaczeniu należy traktować jako nakaz zastosowania narzędzi umożliwiających obiektywizację procesu decyzyjnego.

Samo dążenie do oparcia prawa konkurencji na „twardych” danych nie jest niczym nowym. Amerykańskie prawo antytrustowe od lat siedemdziesiątych XX wieku w sposób zorganizowany czerpie z dorobku ekonomistów, natomiast w Europie tak zwane „bardziej ekonomiczne podejście” (more economic approach) zostało wprowadzone dwie dekady później, na początku lat dziewięćdziesiątych ubiegłego wieku $^{27}$. Wydaje się, że takie postrzeganie prawa konkurencji powinno wiązać się

25 H.A. Simon, A behavioral model..., s. 241; idem, Models of My Life, Boston 1996, s. 165.

26 Zob. R.B. McKenzie, op. cit., s. 118-124.

27 A.C. Witt, The More Economic Approach to EU Antitrust Law, Oxford 2016, s. 10-26. 
z postulatem racjonalnego prawodawcy. Naturalną konsekwencją posiadania dobrego (ale nie absolutnie pełnego) rozeznania w realiach rynkowych będzie bowiem podejmowanie decyzji odnośnie do kształtu rozwiązań prawnych na podstawie naukowo weryfikowalnych merytorycznych przesłanek. Prima facie przekonująco bowiem brzmi argument, że nie po to prawodawca podejmuje wysiłek analityczny, badając obszar swojej przyszłej ingerencji, żeby później miał się zachowywać irracjonalnie, ignorując zebrane dane ${ }^{28}$. Tym samym należałoby skonkludować, że odstąpienie przez normodawcę od „bardziej ekonomicznego podejścia” jest irracjonalne ${ }^{29}$.

Przyjmując wyidealizowaną wizję prawodawcy, opisane stanowisko, które $\mathrm{w}$ istocie było od bardzo dawna postulowane (zanim jeszcze „bardziej ekonomiczne podejście" zostało wyartykułowane), należy uznać za oczywiście słuszne ${ }^{30}$. Jak prawie każda dobrze brzmiąca teoria nie wytrzymuje jednak kontaktu z rzeczywistością. Zdaniem autora zasadniczy problem rysujący się w kontekście tytułowego zagadnienia można sprowadzić do pytania: czy wiedza na temat racjonalnych przedsiębiorstw tworzy racjonalnego prawodawcę? Autor uważa, że odpowiedź jest przecząca. Przede wszystkim w toku dotychczasowych rozważań wskazano, że wyzwania związane z oceną wzorca zachowań konstytuującego racjonalne przedsiębiorstwo koncentrują się wokół niedostatków danych utrudniających lub uniemożliwiających wytyczenie optymalnego, racjonalnego, kursu. Same zaś obiektywne przesłanki racjonalności ekonomicznej na pewnym poziomie ogólności są wyznaczalne. Tego samego nie można powiedzieć o kryteriach oceny racjonalności prawodawcy.

Analizując działania racjonalnego prawodawcy od strony czysto formalnej, można przywołać przesłanki sformułowane przez Lona L. Fullera, który wskazał na wymóg ogólności rozumianej jako sformułowanie zakresu za pomocą generalnych i abstrakcyjnych kategorii, nie zaś w odniesieniu do konkretnej sytuacji; a także wymogi odpowiedniego ogłoszenia, nieretroakcji, niesprzeczności, wystarczającej jasności i stałości. Fuller wskazywał również, że prawo musi być skonstruowane w sposób umożliwiający jego przestrzeganie (niewymagające rzeczy niemożliwych), a praktyka jego stosowania nie może być rozbieżna z verba legis ${ }^{31}$. O ile formalne rozumienie racjonalności prawa jest niekontrowersyjne i powszechnie akceptowane, poza brzegowymi przypadkami wynikającymi przede wszystkim z rażącego (i przez to stwierdzalnego prima facie) naruszenia

28 Należy zastrzec, że przedstawiony w tekście argument jest celowo przerysowany, uproszczony na potrzeby dyskusji. $Z$ posiadania danych na temat sytuacji rynkowej nie można wyprowadzić jednoznacznej rekomendacji dla prawodawcy. Zatem z powyższego twierdzenia nie wynika, w jakim zakresie prawodawca uwzględnia posiadane informacje i jak mogą się one przełożyć na kształt prawa, co zostanie opisane w dalszej części niniejszego opracowania.

29 Zupełne pominięcie analizy rynku podczas procesu legislacyjnego albo podejmowania decyzji przez regulatora byłoby podstawą skutecznego wzruszenia tworzonego aktu z powodu braku odpowiedniego uzasadnienia, zatem naruszenia proceduralnego, zupełnie niezwiązanego z kwestią oceny racjonalności. Jednak taka sytuacja w praktyce będzie rzadko występować.

30 Zob. m.in. założenia idealizacyjne prawodawcy formułowane przez Leszka Nowaka (idem, Interpretacja prawnicza: studium z metodologii prawoznawstwa, Warszawa 1973, s. 33 n.).

${ }^{31}$ L.L. Fuller, Moralność prawa, Warszawa 2004, s. 69-70.

Przegląd Prawa i Administracji CXX, 2020, cz. 1 i 2

(C) for this edition by CNS 
zasad praworządności w państwie, nie dostarcza użytecznych informacji. Pomija bowiem całkowicie element oceny aksjologii stojącej za konkretnym działaniem prawodawcy, który przecież działa z pobudek politycznych swoistych dla uwarunkowań lokalnych, czyli kelsenowskiego Wirksamkeit ${ }^{32}$.

Można powiedzieć, że analiza racjonalności przedsiębiorstw mieści się w formalistycznym postrzeganiu racjonalności prawa, gdyż skupia się przede wszystkim na procesie działań prawodawczych, a nie na materialnoprawnej treści verba legis. Przeprowadzenie kompleksowej oceny skutków regulacji (czyli ocena racjonalnej reakcji przedsiębiorstw) będzie zatem jednym z warunków sine qua non działań racjonalnego prawodawcy. Jest to bowiem element należytego uzasadnienia aktu prawnego/działania regulatora. Natomiast na podstawie formalnych kryteriów ,jakości” procesu legislacyjnego nie można realistycznie oczekiwać żadnego konkretnego kształtu rozwiązania prawnego.

W kontekście zarysowanych wątpliwości stosowana jest dystynkcja między prawodawcą racjonalnym a doskonałym ${ }^{33}$. Ten pierwszy wyposażony jest jedynie w minimum przymiotów w postaci kompetencji językowych, dysponuje możliwie najlepiej uzasadnioną wiedzą, przestrzega zasady określonego systemu ocen moralnych; tym samym racjonalność odnosi się do wewnętrznej prakseologii skutecznych działan ${ }^{34}$. Tymczasem prawodawca doskonały ma możliwość wypracowania absolutnie optymalnego rezultatu ${ }^{35}$.

Choć nie ulega wątpliwości, że doskonałość (nie tylko prawodawcy) jest jedynie postulowanym stanem idealnym, nieosiągalnym nigdzie w praktyce, to jej traktowanie jako pożądanego stanu, do którego legislator powinien dążyć, jest obarczone tym samym błędem co opisywane traktowanie gospodarczej racjonalności jako obiektywnej koncepcji. Tymczasem tak jak działania przedsiębiorstw nie można analizować bez uwzględnienia natury ludzkiej, tak samo nie można oceniać prawa bez analizy uwarunkowań społeczno-politycznych ${ }^{36}$, czyli bez uwzględnienia celów, którym służy ${ }^{37}$.

32 Cytowany w: L.Wintgens, op. cit., s. 22.

33 L. Nowak, op. cit., s. 33 n.; J. Wróblewski, Wybrane zagadnienia metodologiczne dogmatyki prawa, [w:] Zagadnienia metodologiczne prawoznawstwa. Materiaty z sesji naukowej, Łódź, 27-28 marca 1980 r., red. J. Wróblewski, Wrocław-Warszawa 1982, s. 135.

34 J. Wróblewski, op. cit., s. 135.

35 Ibidem.

36 W starszych opracowaniach (np. J. Bafia, Zasady tworzenia prawa, Warszawa 1980, s. 20) spotyka się pogląd, że aksjologia przyjmowana przez prawodawców stanowi zupełnie odrębną kategorię. Częściowo można się z tym poglądem zgodzić w tym sensie, że motywacja legislatora podlega w pierwszym rzędzie ocenie w kategoriach politycznych. Natomiast zupełne pominięcie tego elementu $\mathrm{w}$ analizie racjonalności prawa, sprowadzające ocenę tego prawa do formalnych przesłanek procesu legislacyjnego, należy raczej tłumaczyć ówczesnymi realiami politycznymi i traktować w kategoriach anachronizmu.

37 Nawet jeżeli same cele prawodawcy mogą być oceniane w pierwszym rzędzie w kategoriach politycznych.

Przegląd Prawa i Administracji CXX, 2020, cz. 1 i 2

(C) for this edition by CNS 
Jeżeli więc owe cele wynikają z partykularnych uwarunkowań życia politycznego (co jest nieuniknione w każdym demokratycznym systemie) i tym samym ich zmiany są dyktowane kalendarzem wyborczym, nie wydaje się, żeby można było traktować cele prawa konkurencji jako autonomiczne i izolowane od czynników wpływających na kształt pozostałych obszarów systemu prawnego ${ }^{38}$. Można zatem konkludować, że jedynym kryterium racjonalnego prawodawcy, jakie można praktycznie powiązać z założeniem racjonalnego przedsiębiorstwa, jest formalna poprawność ingerencji, manifestująca się wpisaniem w założenia funkcjonującego od dawna „bardziej ekonomicznego podejścia”39.

\title{
THE ASSUMPTION OF UNDERTAKINGS' RATIONALITY AS A RATIONAL ASSUMPTION OF LAWMAKER IN THE FIELD OF COMPETITION LAW - A PROBLEM OUTLINE
}

\author{
Summary
}

The paper is dedicated to issues related to the extent and limits of the rational undertaking assumption by lawmakers and regulators in the sphere of competition law. The analysis covers the issue of interpretation of economic rationality, the ability of forecasting undertakings' rational behaviour and how drawing from economic acquis could translate into rational lawmaking.

Keywords: rationality, competition law, bounded rationality, More Economic Approach

\section{BIBLIOGRAFIA}

Areeda P.E., Hovenkamp H., Antitrust Law: An Analysis of Antitrust Principles and Their Application, New York 2006.

Bafia J., Zasady tworzenia prawa, Warszawa 1980.

Borucka-Arctowa M., Sprawiedliwość proceduralna a orzecznictwo Trybunatu Konstytucyjnego i jego rola w okresie przemian systemu prawa, [w:] Konstytucja i gwarancje jej przestrzegania. Księga pamiątkowa ku czci Prof. Janiny Zakrzewskiej, red. J. Trzciński, A. Jankiewicz, Warszawa 1996.

38 Poza tym, przyjmując optykę krajową, można wskazać, że prawo konkurencji w sensie formalnym podlega modyfikacjom w drodze zwykłej procedury legislacyjnej, nie jest więc w żaden szczególny sposób wyodrębnione, co mogłoby uzasadniać jego specjalne traktowanie przez prawodawcę.

39 Jest to podejście w istocie wpisujące się w wyrażany od dawna (to jest przed akcesją Polski do UE) pogląd, że procedury są gwarancją racjonalności prawodawcy. Innymi słowy, ograniczają ocenę racjonalności do tego, ,jak” prawo jest tworzone, nie zaś „co” powstaje. Zob. M. Borucka-Arctowa, Sprawiedliwość proceduralna a orzecznictwo Trybunału Konstytucyjnego i jego rola w okresie przemian systemu prawa, [w:] Konstytucja i gwarancje jej przestrzegania. Ksiega pamiątkowa ku czci Prof. Janiny Zakrzewskiej, red. J. Trzciński, A. Jankiewicz, Warszawa 1996, s. 27. 
Buchanan J.M., There is a science of economics, [w:] idem, Post-Socialist Political Economy: Selected Essays, Cheltenham 1997.

Elster J., When rationality fails, [w:] The Limits of Rationality, red. K.S. Cook, M. Levi, Chicago-London 1990.

Fuller L.L., Moralność prawa, Warszawa 2004.

Gromski W., Racjonalny prawodawca, [w:] Encyklopedia prawa, red. U. Kalina-Prasznic, Warszawa 2007.

Hovenkamp H., The Antitrust Enterprise, Cambridge, MA 2005.

Issacharoff S., Can there be a behavioral law and economics?, „Vanderbilt Law Review” 51, 1998, s. $1729-1747$.

Kalinowski M., Ekonomiczne meandry racjonalności, „Studia Ekonomiczne” 180, 2014, cz. 1.

Korobkin R.B., Ulen T.S., Law and behavioral science: Removing the rationality assumption from law and economics, „California Law Review” 88, 2000, nr 4, s. 1051-1144.

Kotlarek P., Racjonalność w ujęciu ekonomii behawioralnej, „Studia Ekonomiczne” 2014, nr 180, cz. 1, s. 106-116.

Leslie C.R., Rationality analysis in antitrust, „University of Pennsylvania Law Review” 158, 2010, nr 2, s. 261-353.

McKenzie R.B., Predictably Rational? In Search of Defenses for Rational Behavior in Economics, Heidelberg-Dordrecht 2010.

Nowak L., Interpretacja prawnicza: studium z metodologii prawoznawstwa, Warszawa 1973.

Piśniak M., Ryzyko w teorii podejmowania decyzji, „Zeszyty Naukowe Politechniki Częstochowskiej - Zarządzanie" 2015, nr 19, s. 116-126.

Rutherford M., Rational expectations and keynesian uncertainty: A critique, „Journal of Post Keynesian Economics" 6, 1984, nr 3, s. 377-387.

Selten R., Features of experimentally observed bounded rationality, „European Economic Review” 42, 1998, nr 3-5, s. 413-436.

Simon H.A., A behavioral model of rational choice, „The Quarterly Journal of Economics” 69, 1955, nr 1, s. 99-118.

Simon H.A., Method and Appraisal in Economics, Cambridge, MA 1976.

Simon H.A., Models of Man: Social and Rational; Mathematical Essays on Rational Human Behavior in Society Setting, New York 1957.

Simon H.A., Models of My Life, Boston 1996.

Tomer J.F., What is behavioral economics?, „The Journal of Socio-Economics” 36, 2007, nr 3, s. 463-479.

Wintgens L., The rational legislator revisited. Bounded rationality and legisprudence, [w:] The Rationality and Justification of Legislation, red. L. Wintgens, D. Oliver-Lalana, Heidelberg 2013.

Witt A.C., The More Economic Approach to EU Antitrust Law, Oxford 2016.

Wróblewski J., Wybrane zagadnienia metodologiczne dogmatyki prawa, [w:] Zagadnienia metodologiczne prawoznawstwa. Materiały z sesji naukowej, Łódź, 27-28 marca 1980 r., red. J. Wróblewski, Wrocław-Warszawa 1982.

Zachorowska A., Ryzyko działalności inwestycyjnej przedsiębiorstw, Warszawa 2006.

Zouboulakis M., The Varieties of Economic Rationality: From Adam Smith to Contemporary Behavioural and Evolutionary Economics, Cheltenham 2014. 